\title{
Cascading effects of the ctenophore Mnemiopsis leidyi on the planktonic food web in a nutrient-limited estuarine system
}

\author{
J. Dinasquet ${ }^{1,2}$, J. Titelman ${ }^{3}$, L. F. Møller ${ }^{4}$, O. Setälä ${ }^{5}$, L. Granhag ${ }^{4}$, T. Andersen ${ }^{3}$, \\ U. Båmstedt ${ }^{6}$, M. Haraldsson ${ }^{4}$, A. Hosia ${ }^{7}$, T. Katajisto ${ }^{5}$, T. Kragh ${ }^{8}$, J. Kuparinen ${ }^{5}$, \\ M.-L. Schrøter ${ }^{1}$, M. Søndergaard ${ }^{8}$, P. Tiselius ${ }^{4}$, L. Riemann ${ }^{1,2, *}$ \\ ${ }^{1}$ Department of Natural Sciences, Linnaeus University, Kalmar, 39182 Kalmar, Sweden \\ ${ }^{2}$ Marine Biological Section, University of Copenhagen, 3000 Helsingør, Denmark \\ ${ }^{3}$ Department of Biology, University of Oslo, 0316 Oslo, Norway \\ ${ }^{4}$ Department of Biological and Environmental Sciences-Kristineberg, University of Gothenburg, 40530 Gothenburg, Sweden \\ ${ }^{5}$ Department of Environmental Sciences, University of Helsinki, 00014 Helsinki, Finland \\ ${ }^{6}$ Department of Ecology and Environmental Sciences, Umeå University, 90187 Umeå, Sweden \\ ${ }^{7}$ Institute of Marine Research, 5817 Bergen, Norway \\ ${ }^{8}$ Freshwater Biological Laboratory, University of Copenhagen, 3400 Hillerød, Denmark
}

\begin{abstract}
Increasing biomasses of gelatinous zooplankton presumably have major implications for the structure and function of marine food webs at large; however, current data on lower trophic levels are scarce, as most studies have focused on the immediate effects on zooplankton and fish larvae only. We examined the short-term impact of larvae and adults of the invasive ctenophore Mnemiopsis leidyi on a summer planktonic food web in the estuarine southern Baltic Sea, with special emphasis on the microbial loop. Grazing by $M$. leidyi reduced the mesozooplankton biomass, followed by increased dinoflagellate biomass in treatments with $M$. leidyi. While chlorophyll $a$ increased most in the treatments with $M$. leidyi, small phytoplankton and ciliates decreased in all treatments. $M$. leidyi had a slight effect on bacterial abundance, but not on bacterial production, ectoenzymatic activities, or community composition. Undetectable levels of phosphate and a gradual accumulation of dissolved organic carbon during the experiment suggested a malfunctioning microbial loop scenario. The experiment shows that direct and indirect short-term effects of $M$. leidyi on the estuarine food web are limited to higher trophic levels and indicates that top-down and bottom-up consequences of $M$. leidyi expansions on the microbial loop will likely depend on local nutrient conditions.
\end{abstract}

KEY WORDS: Bacterioplankton · Nanoflagellates - Microbial loop · Trophic levels $\cdot$ Ciliates · Baltic Sea Resale or republication not permitted without written consent of the publisher

\section{INTRODUCTION}

Episodic occurrences of jellyfish (cnidarian and ctenophore) blooms occur worldwide, with direct consequences for fisheries and coastal industry (Shiganova 1998, Mills 2001, Oguz et al. 2008, Rich- ardson et al. 2009, Acuña et al. 2011). Changes in trophic structure from dominance of fish to jellyfish may have large effects on the biogeochemical cycling of carbon and nutrients (Pitt et al. 2009). For instance, grazing by jellyfish on zooplankton may regulate biomass and structure in the planktonic food 
web at large (Stibor et al. 2004, Turk et al. 2008). Also, jellyfish may stimulate bacterioplankton growth by direct release of nutrients from tissue, mucus secretion, excretion, and sloppy feeding (Nemazie et al. 1993, Hansson \& Norrman 1995, Riemann et al. 2006, Titelman et al. 2006, Turk et al. 2008, Pitt et al. 2009, Condon et al. 2011). Hence, through both top-down and bottom-up effects, jellyfish may have pronounced consequences for planktonic food web structure and ecosystem function.

The lobate ctenophore Mnemiopsis leidyi is native to estuaries of the Atlantic coast of North and South America (Kremer 1994) but has been accidentally introduced to regions such as the Black and Caspian Seas (Finenko et al. 2006), the Mediterranean Sea (Shiganova et al. 2001), and more recently to the North Sea and the southern part of the Baltic Sea (Janas \& Zgrundo 2007, Riisgard et al. 2007, Tendal et al. 2007, Javidpour et al. 2009). The M. leidyi invasion of the Black Sea had deleterious consequences for mesozooplankton populations, and also coincided with the collapse of major fisheries (Oguz et al. 2008, Roohi et al. 2010). The ecological consequences of its proliferation in other marine areas are therefore a matter of concern (Shiganova et al. 2001, Jaspers et al. 2011).

Feeding mechanics of Mnemiopsis leidyi develop with ontogeny. While newly hatched tentaculate larvae capture nano- or microplankton such as flagellates and ciliates on their tentacles (Sullivan \& Gifford 2004, 2007), larger larvae can also feed on larger prey such as mesozooplankton (Stanlaw et al. 1981). Adult M. leidyi entrain both microzooplankton (Stoecker et al. 1987), mesozooplankton, and fish larvae in a feeding current (Purcell et al. 2001, Colin et al. 2010), while $M$. leidyi larvae seem to have a larger proportion of microzooplankton in their diet compared to the lobates (Rapoza et al. 2005). The effective feeding (Colin et al. 2010) and wide environmental tolerance (Purcell et al. 2001) allows M. leidyi to survive in different habitats and to affect multiple food web levels directly or through trophic cascades. Its predation on fish larvae (Govoni \& Olney 1991, Cowan \& Houde 1993, Jaspers et al. 2011) and mesozooplankton (Kremer 1979, Purcell \& Decker 2005) has received ample attention. For instance, summer blooms of M. leidyi can reduce copepod populations to low biomass in estuaries along the US east coast (Sullivan et al. 2001, Costello et al. 2006, Condon \& Steinberg 2008).

Despite extensive documentation of the high predatory impact of Mnemiopsis leidyi, information on propagation of grazing effects or associated bottomup effects is scarce. Grazing by other jellyfish may initiate changes in plankton communities cascading down to the lower trophic levels (Granéli \& Turner 2002, Stibor et al. 2004, Pitt et al. 2007). However, experiments of the conceivably complex consequences of top-down and bottom-up drivers associated with presence and activity of $M$. leidyi is currently lacking, in particular relative to dynamics at the lower trophic levels. Large effects, also at the bacterial level, would be anticipated since bacteria may utilize dissolved organic matter released from jellyfish tissue (Hansson \& Norrman 1995, Titelman et al. 2006, Condon et al. 2011), thereby affecting food web structure and nutrient cycling (Condon et al. 2011). In this experimental mesocosm study, we examined short-term effects of larvae and adults of $M$. leidyi on a temperate estuarine plankton food web.

\section{MATERIALS AND METHODS}

Food web effects of Mnemiopsis leidyi (adults and larvae) were examined in water obtained from the estuarine southern Baltic Sea amended with cultivated $M$. leidyi. The experimental tanks were not supplemented with nutrients in order to examine food web responses under the conditions prevailing in situ at this time of the year.

\section{Mnemiopsis leidyi maintenance}

In November 2008, adult M. leidyi were collected from surface waters of the Gullmarsfjorden on the Swedish west coast $\left(58^{\circ} 81^{\prime} 50^{\prime \prime} \mathrm{N}, 11^{\circ} 82^{\prime} 70^{\prime \prime} \mathrm{E}\right)$. In the laboratory, continuous cultures of the ctenophores were maintained in $50 \mathrm{l}$ containers $\left(16^{\circ} \mathrm{C}\right.$, salinity 32) and fed cultivated copepods (Acartia tonsa) and locally collected zooplankton. Specimens were gradually acclimatized to the Baltic Sea salinity of 6.9 over a period of $2 \mathrm{wk}$ prior to the experiment.

\section{Mesocosm set-up}

The experiment was carried out indoors from 19 to 26 August 2009. The setup consisted of 3 treatments, each with 4 replicates: a control without Mnemiopsis leidyi and 2 treatments amended with larvae (median size $1.5 \mathrm{~mm})$ or adults $(15 \pm 2 \mathrm{~mm}$ oral-aboral length, mean $\pm \mathrm{SD}$ ), corresponding to $50 \mathrm{~g}$ wet weight $\mathrm{m}^{-3}$ (calculated from the linear relationship between log oral-aboral length $\left[\mathrm{L}_{\mathrm{OA}}, \mathrm{mm}\right]$ and log wet weight $[\mathrm{WW}, \mathrm{g}]$ : $\log \mathrm{WW}=1.86 \log \mathrm{L}_{\mathrm{OA}}-1.84$; $\mathrm{R}^{2}=0.91, \mathrm{p}<0.001, \mathrm{~L}$. Friis-Møller unpublished). 
This is similar to abundances measured in the south-

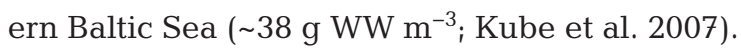

The experimental mesocosms consisted of $300 \mathrm{l}$ acid-washed polyethylene tanks with $200 \mathrm{l}$ of water. The experiment was carried out at in situ temperature $\left(17 \pm 0.3^{\circ} \mathrm{C}\right)$ and salinity (6.9), with a light:dark cycle of $16: 8 \mathrm{~h}$ and a light intensity of $48.7 \mu \mathrm{mol}$ $\mathrm{s}^{-1} \mathrm{~m}^{-2}$ corresponding to the light at $7 \mathrm{~m}$ depth in situ. The positions of the tanks were randomized.

Water was collected at 08:00 h on 18 August 2009 by a pump (tube diameter $=5 \mathrm{~cm}$ ) at $7 \mathrm{~m}$ depth about $12 \mathrm{~km}$ off the island of Öland, southern Sweden $\left(56^{\circ}\right.$ $53^{\prime} 25^{\prime \prime} \mathrm{N}, 17^{\circ} 04^{\prime} 07^{\prime \prime} \mathrm{E}_{\text {; }} \sim 60 \mathrm{~m}$ total depth) and transported to the laboratory in $1 \mathrm{~m}^{3}$ containers. The water was inversely filtered through a $90 \mu \mathrm{m}$ mesh $(13 \mathrm{~cm}$ diameter) directly into the tanks using gravity-driven flow. To ensure a homogenous distribution of zooplankton, we manually portioned out the $>90 \mu \mathrm{m}$ fraction between the tanks. This was conducted by first inverse filtering $(90 \mu \mathrm{m})$ the combined remaining water fractions from the initial containers down to about $80 \mathrm{l}$. Of these $80 \mathrm{l}$, about $75 \mathrm{l}$ were then divided among 32 bottles, using a series of 100 to $300 \mathrm{ml}$ portions, where excess water was removed by gentle submerged filtration through a $45 \mu \mathrm{m}$ mesh. Of the 32 bottles containing $>90 \mu \mathrm{m}$ zooplankton, 24 bottles were divided equally among the 12 tanks. Observations under a stereomicroscope ensured that mesozooplankton were in good condition. The remaining 8 bottles were preserved in formalin ( $2 \%$ final concentration) for enumeration of zooplankton start concentrations. The portioning out and preservation of the bottles was randomized. The filled tanks were left overnight.

The experiment started the following morning when Mnemiopsis leidyi specimens were added to the tanks. M. leidyi were kept submerged at all times. Immediately prior to the start of the experiment, the M. leidyi were rinsed with experimental water to minimize the introduction of dissolved organic matter and bacteria into the system. Four portions of individually picked larvae were washed in a submerged $130 \mu \mathrm{m}$ sieve by gently pouring over 101 of $90 \mu \mathrm{m}$-filtered experimental water. The larvae were then introduced to the tanks together with $150 \mathrm{ml}$ of experimental water. The adults were first transferred to experimental water and allowed to acclimatize overnight, and subsequently rinsed in successive baths of $10 \mathrm{l}$ and $0.3 \mathrm{l}$ just prior to the start. Four adults were introduced into each tank, together with $150 \mathrm{ml}$ of experimental water.

\section{Sampling}

The tanks were sampled at $0,6,12,24,36,51,72$, $96,120,144$, and $168 \mathrm{~h}\left(t_{0} \ldots t_{168}\right)$. Prior to sampling, the water was gently mixed, and 31 from each tank were taken out for analysis of various parameters (Table 1). Zooplankton was only sampled at the start and end of the experiment due to the large volumes necessary for accurate enumeration. At each sampling, temperature was measured and Mnemiopsis leidyi specimens were assessed by eye to ensure that they remained healthy.

\section{Inorganic nutrients and dissolved and particulate organic carbon (DOC and POC)}

For each of nitrate+nitrite, ammonia, phosphate, and silica, a $12 \mathrm{ml}$ sample was GF/F filtered into a

Table 1. Scheme showing the sampling for various parameters in the quadruplicate tanks at specific time points $\left(t_{0} \ldots t_{168}\right)$, given in hours. DOC/POC: dissolved/particulate organic carbon; Chl a: chlorophyll $a_{\text {; }}$ Ectoenzymes: ectoenzymatic activity;

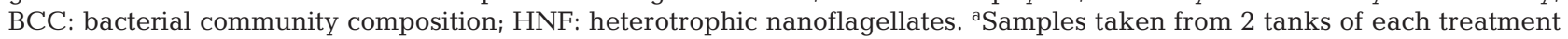

\begin{tabular}{|c|c|c|c|c|c|c|c|c|c|c|c|}
\hline & $t_{0}$ & $t_{6}$ & $t_{12}$ & $t_{24}$ & $t_{36}$ & $t_{51}$ & $t_{72}$ & $t_{96}$ & $t_{120}$ & $t_{144}$ & $t_{168}$ \\
\hline Nutrients & $\mathrm{x}$ & $\mathrm{x}$ & $\mathrm{x}$ & $\mathrm{x}$ & $\mathrm{x}$ & $\mathrm{x}$ & $\mathrm{x}$ & $\mathrm{x}$ & $\mathrm{x}$ & $\mathrm{x}$ & $\mathrm{x}$ \\
\hline DOC/POC & $\mathrm{x}$ & $\mathrm{x}$ & $\mathrm{x}$ & $\mathrm{x}$ & $\mathrm{x}$ & $\mathrm{x}$ & $\mathrm{x}$ & $\mathrm{x}$ & $\mathrm{x}$ & $\mathrm{x}$ & $\mathrm{x}$ \\
\hline Chl a & $\mathrm{x}$ & $\mathrm{x}$ & $\mathrm{x}$ & $\mathrm{x}$ & $\mathrm{x}$ & $\mathrm{x}$ & $\mathrm{x}$ & $\mathrm{x}$ & $\mathrm{x}$ & $\mathrm{x}$ & $\mathrm{x}$ \\
\hline Bacterial abundance & $\mathrm{x}$ & $\mathrm{x}$ & $\mathrm{x}$ & $\mathrm{x}$ & $\mathrm{x}$ & $\mathrm{x}$ & $\mathrm{x}$ & $\mathrm{x}$ & $\mathrm{x}$ & $\mathrm{x}$ & $\mathrm{x}$ \\
\hline Bacterial production & $\mathrm{x}$ & $\mathrm{x}$ & $\mathrm{x}$ & $\mathrm{x}$ & $\mathrm{x}$ & $\mathrm{x}$ & $\mathrm{x}$ & $\mathrm{x}$ & $\mathrm{x}$ & $\mathrm{x}$ & $\mathrm{x}$ \\
\hline Ectoenzymes & $\mathrm{x}$ & $\mathrm{x}$ & $\mathrm{x}$ & $\mathrm{x}$ & $\mathrm{x}$ & $\mathrm{x}$ & $\mathrm{x}$ & $\mathrm{x}$ & $\mathrm{x}$ & $\mathrm{x}$ & $\mathrm{x}$ \\
\hline $\mathrm{BCC}$ & $\mathrm{x}$ & $\mathrm{x}$ & $\mathrm{x}$ & $\mathrm{x}$ & $\mathrm{x}$ & $\mathrm{x}$ & $\mathrm{x}$ & $\mathrm{x}$ & $\mathrm{x}$ & $\mathrm{x}$ & $\mathrm{x}$ \\
\hline Phytoplankton & $\mathrm{x}$ & & & & & $\mathrm{x}^{\mathrm{a}}$ & & & $x^{a}$ & $x^{a}$ & $\mathrm{x}$ \\
\hline Microzooplankton & $\mathrm{x}$ & & & & & $\mathrm{x}^{\mathrm{a}}$ & & & $x^{a}$ & $\mathrm{x}^{\mathrm{a}}$ & $\mathrm{x}$ \\
\hline HNF & $\mathrm{x}$ & & & & & $\mathrm{x}^{\mathrm{a}}$ & & & $\mathrm{x}^{\mathrm{a}}$ & $\mathrm{x}^{\mathrm{a}}$ & $\mathrm{x}$ \\
\hline Zooplankton & $\mathrm{x}$ & & & & & & & & & & $\mathrm{x}$ \\
\hline
\end{tabular}


$15 \mathrm{ml}$ polypropylene tube and frozen. Samples were analyzed with a Bran \& Luebbe TRAACS 800 autoanalyzer using standard seawater methods (Grasshoff et al. 1983).

Triplicate samples for DOC and POC ( 60 ml) were taken at every sampling during the period of the experiment. Water was filtered through a $25 \mathrm{~mm}$ precombusted Whatman GF/F filter $\left(450^{\circ} \mathrm{C}, 5 \mathrm{~h}\right)$, the first $20 \mathrm{ml}$ of filtrate were discarded, and the next $12 \mathrm{ml}$ were acidified with $120 \mu \mathrm{l} 2 \mathrm{M} \mathrm{HCl}$, and analyzed for DOC as described by Kragh \& Søndergaard (2004) using a Shimadzu TOC-V. The calibration consisted of a 3-point curve $\left(r^{2}>0.999\right)$, and at least 3 injections with a maximum of 5 were made for each sample. Each sample run included standard and blank samples interspersed throughout the sample run. Deepocean and blank samples provided by J. Sharp (University of Delaware, US) served as quality controls. For POC analysis, the GF/F filters were dried at $40^{\circ} \mathrm{C}$ and stored in a dessicator at room temperature until analysis. Prior to measurement, the filters were exposed to $\mathrm{HCl}$ fumes for $4 \mathrm{~h}$ in a desiccator. The filters were analyzed by high-temperature combustion using a system made up of a Struers Carbolite Furnace set at $600^{\circ} \mathrm{C}$, an ADC-225-Mk3 NDIR analyzer, and a Picotech ADC-20 datalogger.

\section{Chlorophyll a}

Duplicate samples (300 to $500 \mathrm{ml}$ ) were filtered onto $47 \mathrm{~mm}$ GF/F filters and frozen. Chlorophyll a (chl a) was extracted in ethanol (Jespersen \& Christoffersen 1987) and measured on a Turner design 10-AU fluorometer (excitation 340 to $500 \mathrm{~nm}$ band pass; emission > 665 nm cut-off) calibrated with a standard chl a solution (Sigma).

\section{Enumeration of heterotrophic nanoflagellates (HNF), microzooplankton, and phytoplankton}

For the enumeration of HNF, $40 \mathrm{ml}$ samples were fixed with $0.2 \mu \mathrm{m}$-filtered glutaraldehyde $(1.2 \%$ final concentration) and stored at $4^{\circ} \mathrm{C}$. A subsample of $5 \mathrm{ml}$ was stained with proflavine, filtered onto $0.2 \mu \mathrm{m}$ polycarbonate filters (Kuuppo-Leinikki \& Kuosa 1989), and $\geq 50$ microscopy fields were counted from each filter using epifluorescence microscopy (Leica Aristoplan) at $1000 \times$ magnification. The carbon contents of small, medium, and large flagellates (averages, based on most common shapes: 5, 32, and $135 \mu^{3}, H$. Kuosa unpublished) were calcu- lated according to Menden-Deuer \& Lessard (2000). For microzooplankton and phytoplankton, $300 \mathrm{ml}$ samples were fixed with acid Lugol's solution (1\% final concentration) and subsequently settled in 50 $\mathrm{ml}$ chambers for $24 \mathrm{~h}$ (Utermöhl 1958). The cells were counted under an inverted light microscope (Leica DMIL) at 100 to $400 \times$ magnification. Large cells were counted from the whole settling chamber area, while small cells were counted from 200 fields of vision. Geometric formulae were used to estimate cell volumes (Edler 1979), which were converted to biomass using $0.19 \mathrm{pg} \mathrm{C} \mathrm{mm}^{-3}$ (Putt \& Stoecker 1989).

\section{Zooplankton}

An extra tank with experimental water was filled at the same time as the 12 mesocosms. Water from this tank was used to quantify zooplankters $<90 \mu \mathrm{m}$ at the beginning of the experiment (data were included in the initial zooplankton biomass). At the termination of the experiment, the entire tank volumes were filtered through a $45 \mu \mathrm{m}$ mesh and the zooplankton preserved in formaldehyde ( $2 \%$ final concentration). Zooplankton were identified and measured at $40 \times$ magnification under a stereomicroscope. Lengths of zooplankton were converted to biomass using regressions for copepods (Berggreen et al. 1988, Hay et al. 1991) or cladocerans (Kankaala \& Johansson 1986).

\section{Bacterial abundance and production}

Samples $(1.5 \mathrm{ml})$ were fixed with electron microscopy grade glutaraldehyde (Sigma; 1\% final concentration), frozen in liquid $\mathrm{N}_{2}$, and stored at $-80^{\circ} \mathrm{C}$. Samples were stained with SYTO 13 (Molecular Probes) and counted on a FASCalibur flow cytometer (Becton Dickinson; Gasol \& del Giorgio 2000) using $1.0 \mu \mathrm{m}$ green fluorescent polymer microspheres (Duke Scientific Corporation) as internal standard in each sample. Fluorescent beads (True counts, Becton Dickinson) were used to calibrate the flow rate. Bacterial production was measured by $\left[{ }^{3} \mathrm{H}\right]$-thymidine incorporation (Fuhrman \& Azam 1982) as modified for microcentrifugation by Smith \& Azam (1992). Triplicate $1.7 \mathrm{ml}$ aliquots were incubated with [methyl- ${ }^{3} \mathrm{H}$ ]-thymidine $(25 \mathrm{nM}$ final concentration, Amersham) in sterile $2.0 \mathrm{ml}$ capacity polypropylene tubes for ca. $1 \mathrm{~h}$ at in situ temperature. Samples with $5 \%$ trichloracetic acid added prior to the addition of 
isotope served as blanks. Thymidine incorporation was converted to carbon production using $1.4 \times 10^{18}$ cells mole ${ }^{-1}$ thymidine incorporated (average calculated from published Baltic Sea data, SE $=0.1 \times 10^{18}$ cells mole $^{-1}$ thymidine, $\mathrm{n}=73$; Helsinki Commission [HELCOM] guidelines). Saturation curves were made beforehand. Cell-specific growth rates were calculated assuming exponential growth and a carbon to cell ratio of $51 \mathrm{fg}$ carbon cell ${ }^{-1}$ (determined by Zweifel et al. 1993 for P-limited bacteria in the Baltic Sea).

\section{Ectoenzymatic activities}

Triplicate $192 \mu \mathrm{l}$ samples were incubated in microplates (Nunc) with fluorogenic substrates (methylumbelliferyl [MUF] and amino-methylcoumarin [AMC] derivatives, Sigma) to determine potential hydrolysis rates. The substrates used (and enzymes assayed) were L-leucine-AMC (aminopeptidase) and MUF $\beta$-D-glucoside (glucosidase). Substrate hydrolysis rates were measured in a plate reader (FluoStar, BMG Labtech) calibrated with standard solutions of MUF and AMC (Sigma) and potential activities at $200 \mu \mathrm{M}$ substrate concentration were measured. Saturation curves were made beforehand.

\section{Bacterial community composition}

Water $(\sim 1$ l) was filtered onto a $0.2 \mu \mathrm{m}, 47 \mathrm{~mm}$ Supor filter (Pall) and frozen at $-80^{\circ} \mathrm{C}$ in $1 \mathrm{ml}$ sucrose lysis buffer $(20 \%$ sucrose, $50 \mathrm{mM}$ EDTA, $50 \mathrm{mM}$ TrisHCl, $\mathrm{pH}=8$ ). DNA was extracted using an enzyme/phenol-chloroform protocol (Boström et al. 2004) and quantified using PicoGreen (Molecular Probes). Bacterial 16S rRNA genes were PCR amplified using puReTaq Ready-To-Go PCR beads (GE Healthcare), $1.5 \mathrm{ng}$ DNA $\mu^{-1}$, and primers GC341F (Muyzer et al. 1993) and 907R (Muyzer \& Smalla 1998) as previously described (Riemann et al. 2006). PCR products were analyzed by denaturing gel gradient electrophoresis (DGGE) as in Riemann et al. (2006). DGGE profiles were made for samples obtained from all tanks at $t_{0,}, t_{72}$, and $t_{168}$.

\section{Statistical analysis}

Several parameters were sampled daily (e.g. chl a, bacterial production and abundance), while most microscopy-based samples were taken only at the beginning and end of the experiment. To avoid the pitfalls of temporal pseudo-replication (Hurlbert 1984), as well as making the analyses more easily comparable across parameters, we used the differences between start and end values for each tank as dependent variables for all parameters, and analyzed the responses to treatment level by 1-way analyses of variance (ANOVAs). An advantage of this approach is that it is quite easy to perform power analysis (i.e. assess the probability of not making a Type 2 error) in addition to standard significance tests based on the estimated probability of making a Type 1 error. Tukey HSD post hoc tests were used to identify significant differences between treatment levels for parameters where the 1-way ANOVA had a significance probability $<0.05$. Statistical analyses were done using the $\mathrm{R}$ statistical computing environment (www.r-project.org).

\section{Power analysis}

Since all response parameters were analyzed by 1way ANOVAs on the changes from beginning to end of the experiment, all $F$-tests will have the same number of degrees of freedom ( 2 and 9 ). This makes it easy to compute the statistical power of these tests from percentiles of the cumulative non-central $F$-distribution with the appropriate degrees of freedom. The power of a statistical test expresses the probability of detecting a true difference between treatments (i.e. not making a Type 2 error), while keeping the Type 1 error probability (i.e. concluding there was a true difference when it actually was just due to random noise) at a fixed level - the customary 0.05 in our case. The chosen design in our experiment ( 3 treatments with 4 replicates each) will have a power of 0.56 if the variance between treatments is equal to the within-treatment variance, and will increase to 0.86 if the variance between treatments is twice as high as within treatments. In order to have a power of $80 \%$, which is often considered a good balance between the risks of Type 1 and 2 errors, the betweentreatment variance needs to be at least 1.71 times higher than the within-treatment variance. This translates to the between-treatment standard deviation needing to be at least $31 \%$ higher than the within-treatment standard deviation $(\sqrt{ } 1.71=1.31)$. It can be shown that this also implies that our design should have $80 \%$ probability of detecting a situation where at least 1 treatment differs from the control by more than $\sqrt{ }(3 \times 1.71)=2.26$ times the within-treatment standard deviation. 


\section{RESULTS}

Mnemiopsis leidyi specimens appeared healthy throughout the experiment. Adults had visibly full guts most of the time and were swimming from the bottom to the surface of the tanks several times per day. Larvae grew during the experiment from $\sim 1.5 \mathrm{~mm}$ to $\sim 3.0 \mathrm{~mm}$ median length.

\section{Environmental parameters}

Nutrient concentrations were low throughout the experiment, with phosphate and nitrite being undetectable at all times (detection limits of 0.01 and $0.05 \mu \mathrm{mol} \mathrm{l}^{-1}$, respectively). Ammonium and nitrate were $<0.31$ and $<0.12 \mu \mathrm{mol} \mathrm{l}{ }^{-1}$, respectively, while silica was always $>3.63 \mu \mathrm{mol} \mathrm{l}^{-1}$ (data not shown). The N:P ratio, based on inorganic nutrients, was $>27$ throughout the experiment. DOC increased between $t_{12}$ and $t_{72}\left(338\right.$ to $364 \mu \mathrm{mol} \mathrm{l^{-1 }}$ ) and then
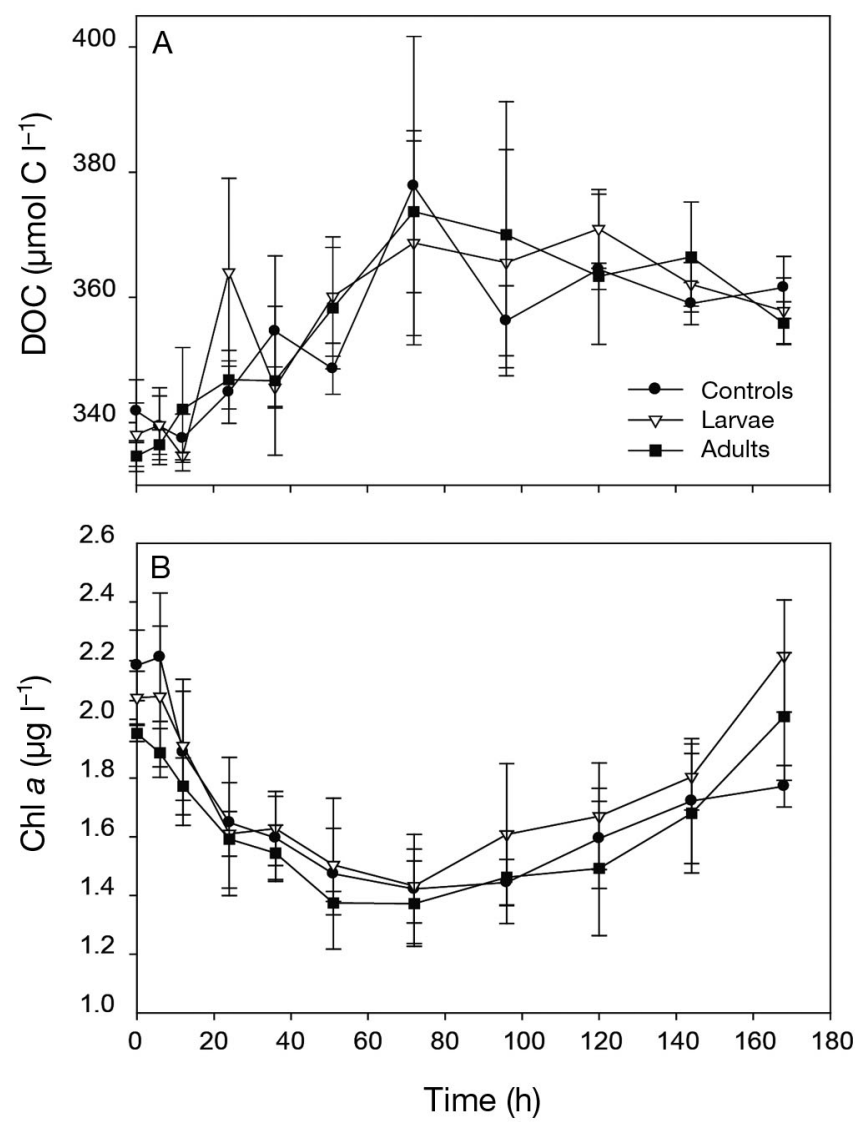

Fig. 1. Concentration of (A) dissolved organic carbon (DOC) and (B) chlorophyll a ( $\mathrm{chl}$ a) as a function of time. Means \pm $\mathrm{SD}$ for 4 replicates remained stable, with no differences between treatments at the end of the experiment $\left(F_{2,9}=\right.$ $0.405, \mathrm{p}=0.68$; Figs. 1A \& 2A). Generally, chl $a$ initially decreased from $2.0 \mu \mathrm{g} \mathrm{l}^{-1}$ to $1.4 \mathrm{\mu g} \mathrm{l}^{-1}$ at $t_{72}$, after which it increased again (Figs. 1B \& 2B). At the end of the experiment, chl a differed between treatments $\left(F_{2,9}=12.598, \mathrm{p}=0.0025\right)$, with the larvae and adult treatments behaving similarly $(p=$ $0.77)$, both with higher values than in the controls $(\mathrm{p}=0.0031$ and $\mathrm{p}=0.0084$, respectively). POC concentrations fluctuated between 332 and $510 \mu \mathrm{mol}$ $1^{-1}$ without differences between treatments $\left(F_{2,9}=\right.$ $2.7819, p=0.11$; Fig. 2C).

\section{Mesozooplankton composition and biomass}

Initially, the cladoceran Bosmina longispina represented $95 \%$ of the mesozooplankton biomass (Fig. 3). A few Acartia tonsa copepodites and nauplii were also observed. At the end of the experiment, differences between treatments were evident for $B$. longispina $\left(F_{2,9}=14.675, \mathrm{p}=0.0015\right)$ and copepodites $\left(F_{2,9}=41.901, \mathrm{p}=0.000028\right)$, where biomasses of both $B$. longispina and copepodites had decreased in the larval and adult treatments compared to their biomasses in the controls $(p<0.00001$ for the respective comparisons).

\section{Phytoplankton composition and biomass}

Detailed taxonomic and functional identifications and quantifications, based on morphology and divisions into size classes, did not reveal any significant differences between treatments (data not shown), and phytoplankton were therefore pooled in coarse taxonomic groups. Phytoflagellates, dinoflagellates, euglenids, and cryptophytes dominated the phytoplankton community, while cyanobacteria and diatoms were rare. The dinoflagellates, of which $68 \%$ were $<20 \mu \mathrm{m}$, generally increased in biomass with differences between treatments $\left(F_{2,9}=19.947, \mathrm{p}=\right.$ 0.00049 ; Figs. 2D \& 4A). The largest increase occurred in the larval treatment reaching a level of $1.77 \mu \mathrm{mol} \mathrm{C} \mathrm{^{-1 }}$, followed by the adult and control treatments ( $\mathrm{p}<0.05$ for all respective comparisons). In contrast, there were no significant treatment effects on euglenids and cryptophytes $\left(F_{2,9}=1.783\right.$, $\mathrm{p}=0.22$ ), which generally decreased (Figs. 2E \& 4B), or other phytoflagellates $\left(F_{2,9}=0.956, \mathrm{p}=\right.$ 0.42 ), which almost doubled during the experiment (Figs. 2F \& 4C). 


\section{Protozoans}

Identification of the ciliates at the genus level did not reveal any differences between treatments (data not shown). Small cells $<30 \mu \mathrm{m}$ (especially Lohmanniella oviformis) dominated the ciliates. Ciliate biomass almost doubled during the first $51 \mathrm{~h}$ to 0.96 umol C $\mathrm{Cl}^{-1}$ and then decreased to low levels (Fig. 4D). In contrast, the biomass of HNF increased in all treatments (Fig. 4E). There were no significant treatment effects on either ciliates $\left(F_{2,9}=1.1961, \mathrm{p}=0.3462\right.$;

Fig. $2 \mathrm{G})$ or HNF $\left(F_{2,9}=3.821, \mathrm{p}=0.063\right.$; Fig. $\left.2 \mathrm{H}\right)$.

\section{Bacterial abundance, activity, and community composition}

Although the development of bacterial abundance differed between treatments $\left(F_{2,9}=4.8494, \mathrm{p}=0.037\right)$, with the larval treatment being lower, the differences
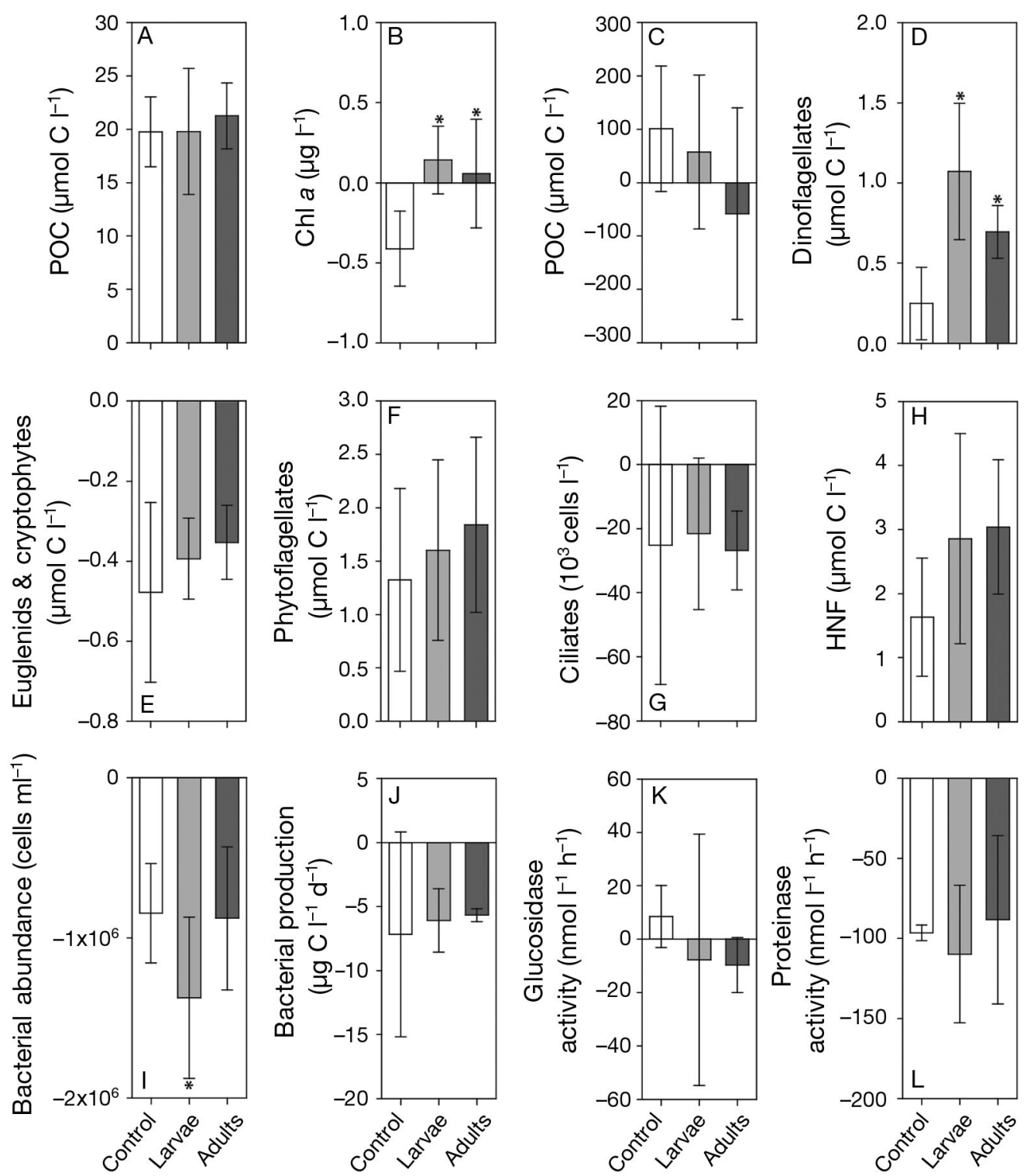

Fig. 2. Changes in tested variables from the start to the end of the experiment for (A) dissolved organic carbon (DOC), (B) chlorophyll a (chl a), (C) particulate organic carbon (POC), (D) dinoflagellates, (E) euglenids and cryptophytes, (F) phytoflagellates, (G) ciliates, (H) heterotrophic nanoflagellates (HNF), (I) bacterial abundance, (J) bacterial production, (K) glucosidase activity, and (L) proteinase activity. Mean $\pm 95 \%$ confidence limits of the change from $t_{0}$ to $t_{168}$ in each of the 4 replicates of each treatment. ${ }^{*}$ : significant difference to the control 


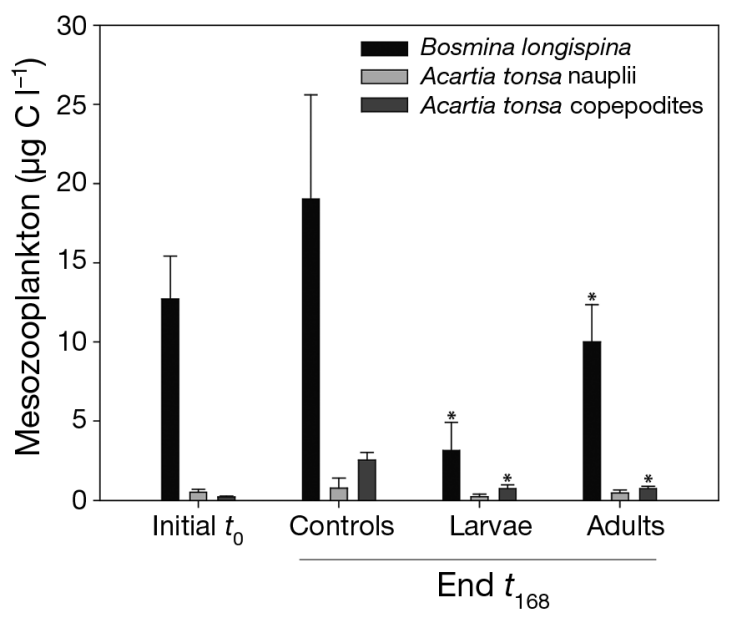

Fig. 3. Mesozooplankton biomass in the control and 2 treatments at the start $\left(t_{0}\right)$ and at the end of the experiment $\left(t_{168}\right)$. Mean $\pm \mathrm{SD}, \mathrm{n}=8$ for $t_{0}$ and $\mathrm{n}=4$ for $t_{168 .}{ }^{*}$ : significant differences to the control
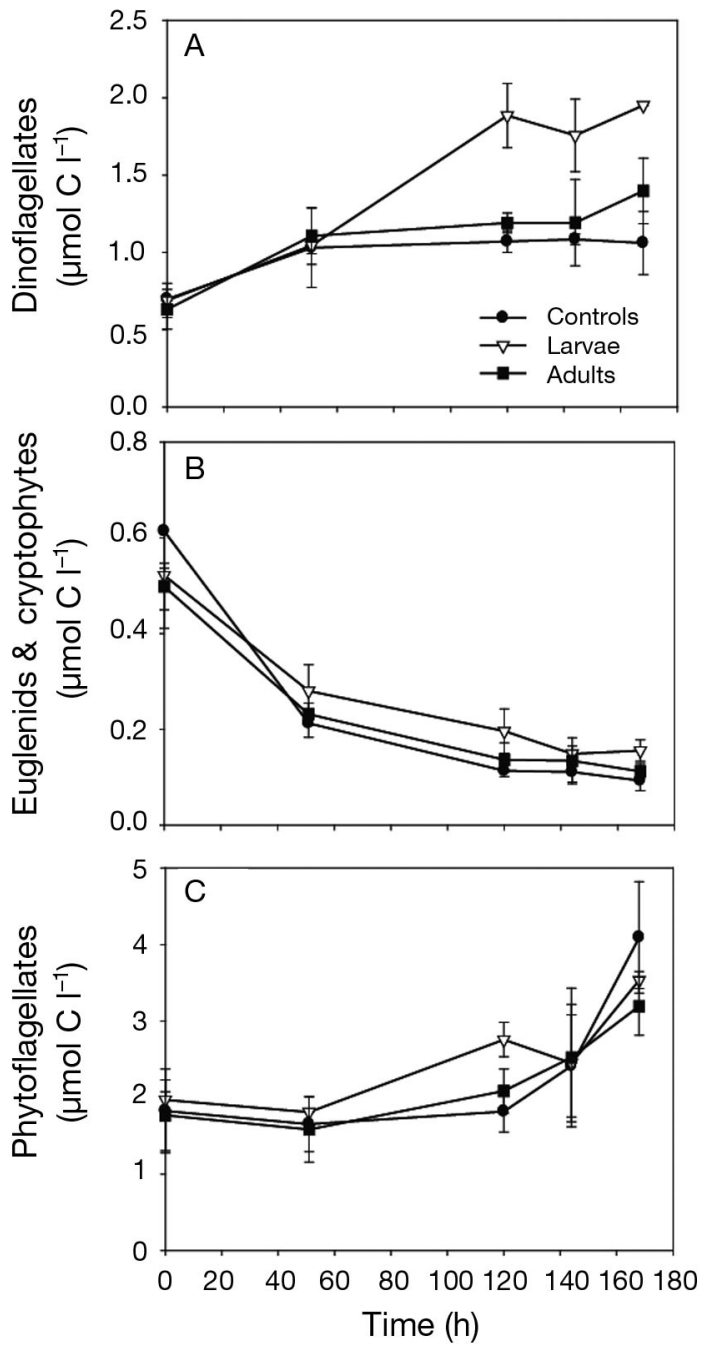

were small $(\mathrm{p}=0.051$ versus the control, and $\mathrm{p}=$ 0.069 versus adults; Fig. 2I). No treatment effect was evident for bacterial production $\left(F_{2,9}=0.2594, \mathrm{p}=\right.$ 0.78; Fig. 2J $)$, glucosidase $\left(F_{2,9}=1.2245, p=0.34\right.$; Fig. $2 \mathrm{~K})$, or proteinase $\left(F_{2,9}=0.7657, \mathrm{p}=0.49\right.$; Fig. $\left.2 \mathrm{~L}\right)$ activities. Similarly, analysis of bacterial community composition by DGGE showed no differences between treatments or changes in composition during the course of the experiment (Fig. 5E). The bacterial abundance increased from $4.6 \times 10^{6}$ cells ml $^{-1}$ at $t_{0}$ until $t_{140}$ and then dropped towards the end of the

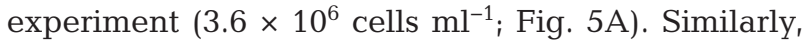
bacterial production increased until $t_{72}\left(23.3 \mu \mathrm{g} \mathrm{C}^{-1}\right.$ $\mathrm{d}^{-1}$ ) and then decreased towards the end (Fig. 5B). Overall, the bacterial assemblage grew slowly with average biomass-specific growth rates of $\leq 0.07 \mathrm{~d}^{-1}$ and no differences between treatments (data not shown). Glucosidase and proteinase activities oscillated throughout the experiment with no obvious
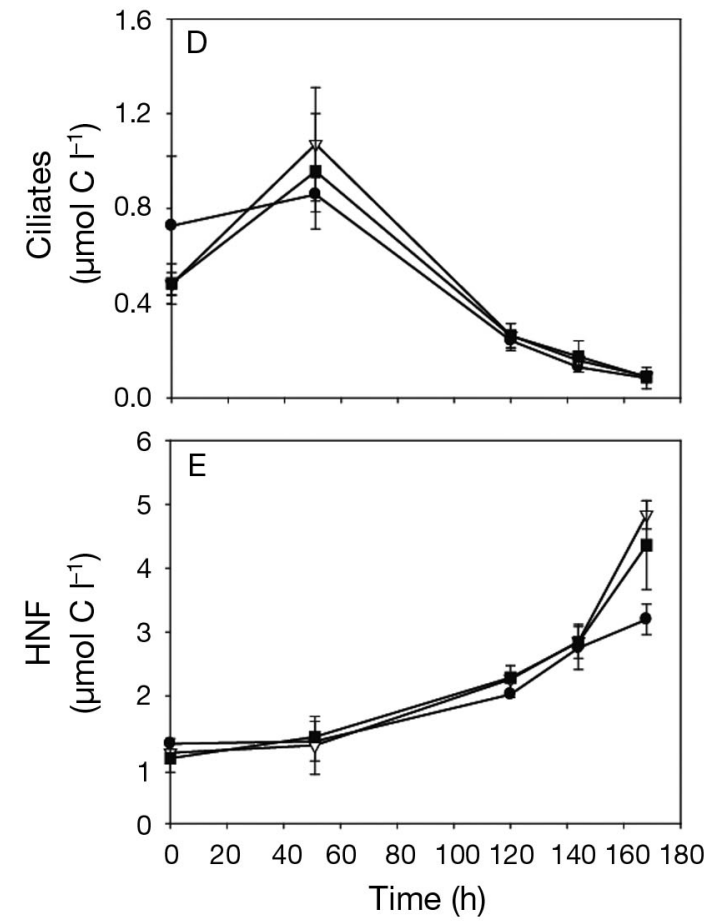

Fig. 4. Biomass of phytoplankton and protozoan groups: (A) dinoflagellates; (B) euglenids and cryptophytes; (C) phytoflagellates; (D) ciliates; and (E) heterotrophic nanoflagellates (HNF). Means $\pm \mathrm{SD} ; \mathrm{n}=2$ of each treatment at $t_{51}, t_{120}, t_{144}$ and $\mathrm{n}=4$ for $t_{0}$ and $t_{168}$ 

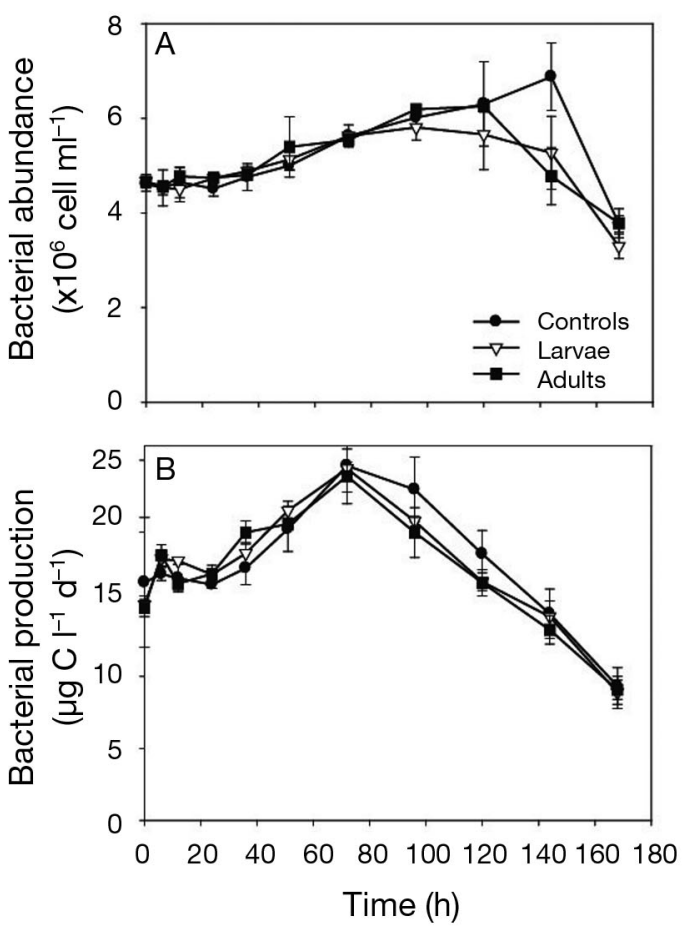

Fig. 5. (A) Bacterial abundance; (B) bacterial production; (C) glucosidase and (D) proteinase activity. Mean \pm SD for 4 replicates. (E) Representative denaturing gradient gel electrophoresis (DGGE) analysis of bacterial community composition in all tanks at $72 \mathrm{~h}$ and for samples from the start $\left(t_{0}\right)$ and end $\left(t_{168}\right)$ of the experiment. Numbers 1 to 12 correspond to tank numbers. DGGE fingerprint comparisons of all tanks at $t_{0}$ and $t_{168}$ showed a similar lack of differences (data not shown)

trends, and showed no differences between treatments (Fig. 5C,D).

\section{DISCUSSION}

Blooms of gelatinous plankton may have consequences for marine planktonic food web dynamics (Mills 2001, Acuña et al. 2011). Particularly, in estuaries, seasonal mass occurrences and the associated decimation of mesozooplankton stocks (Sullivan et al. 2001, Costello et al. 2006) may have detrimental implications for fish recruitment (Oguz et al. 2008). Nevertheless, effects of jellyfish on the lower trophic levels have received limited attention (but see Hansson \& Norrman 1995, Riemann et al. 2006, Titelman et al. 2006, Turk et al. 2008, Pitt et al. 2009, Condon et al. 2011). In our experiment, the short-term grazing
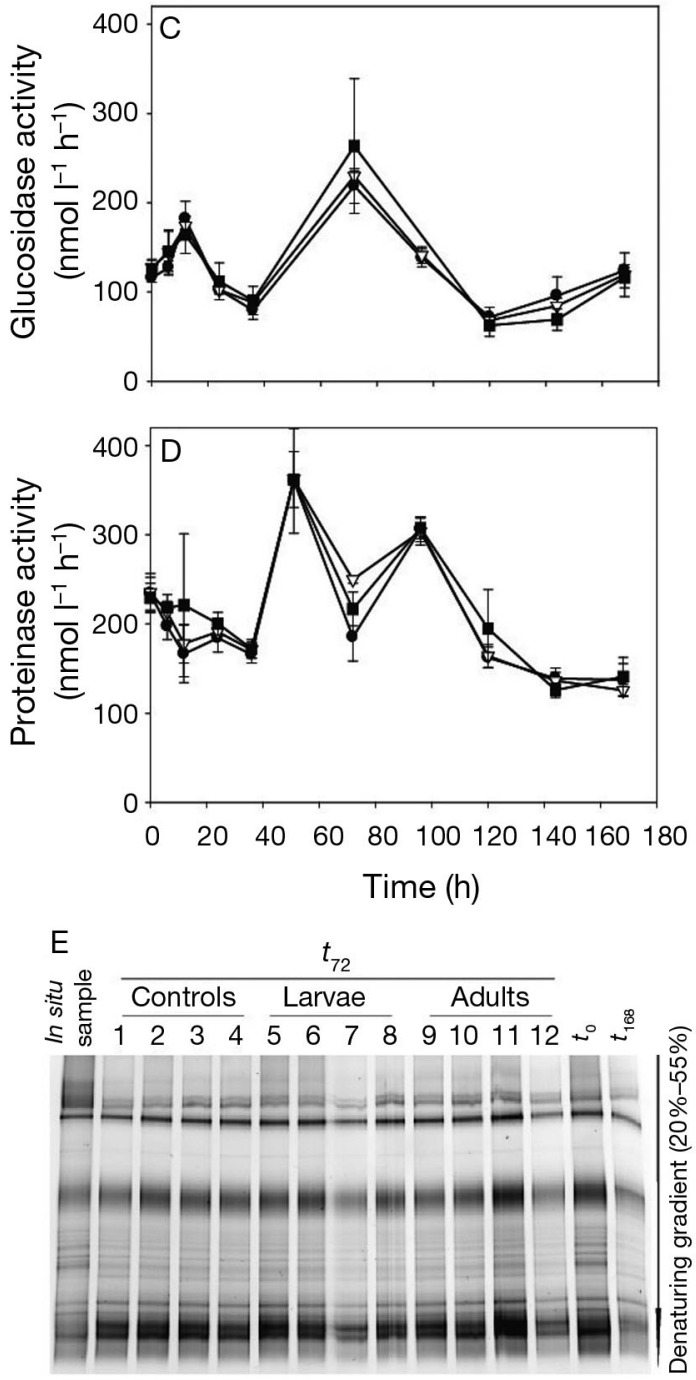

effects of Mnemiopsis leidyi in a nutrient-deprived estuarine environment were limited to the higher trophic levels (mesozooplankton and dinoflagellates), as well as an effect on chl $a$, while bottom-up effects on the microbial levels of the planktonic food web were lacking. These observations indicate that timing, magnitude, and characteristics of food web consequences associated with $M$. leidyi in estuarine environments are linked to local nutrient conditions.

Given the potential of other jellyfish to induce trophic cascades (Stibor et al. 2004, Pitt et al. 2007), and the high predatory capacity of Mnemiopsis leidyi (Colin et al. 2010), we anticipated effects on various trophic levels in our experiment. While grazing by both larvae and adults reduced the mesozooplankton, no direct grazing effects were evident on dinoflagellates, ciliates, phytoplankton, or HNF. This is surprising because all life stages of M. leidyi prey 
on protists, and larvae in particular are omnivorous (Purcell et al. 2001). Nevertheless, the released grazing pressure by the mesozooplankton generated cascade effects towards the end of the experiment, evident as elevated biomass of dinoflagellates and chl a in the adult and larval treatments.

Prey- or size-selective grazing of both Mnemiopsis leidyi (Sullivan \& Gifford 2004, 2007) and Bosmina longispina (Bleiwas \& Stokes 1985), in conjunction with nutrient limitation, could potentially contribute to the observed pattern. Whereas changed copepod biomass often elicits strong cascades due to their high and size-selective grazing (Zöllner et al. 2003, 2009), cascading effects elicited by cladocerans are often dampened or delayed (Sommer \& Stibor 2002, Zöllner et al. 2003, 2009), likely due to their more unselective grazing (Sommer \& Sommer 2006). At the beginning of the experiment, $B$. longispina, which is common in the southern Baltic Sea at this time of year (Hernroth \& Ackefors 1979, Vuorinen et al. 1998), accounted for $>98 \%$ of the mesozooplankton biomass. Although $B$. longispina filters particles $<19 \mu \mathrm{m}$ (Burns 1968, Ross \& Munawar 1981), it can selectively grasp larger prey (Bleiwas \& Stokes 1985). The released grazing pressure by $B$. longispina in the $M$. leidyi treatments may explain the increases in chl $a$ and in dinoflagellates towards the end of the experiment. Moreover, the predominance of a cladoceran per se may have dampened the short-term trophic cascade. In lake mesocosms, the effects of copepod grazing were immediate, whereas for cladocerans, with $>10$-fold higher biomass than in our experiment, only a slight effect on ciliates was detected after $9 \mathrm{~d}$ while an overall predation effect took $15 \mathrm{~d}$ (Zöllner et al. 2003).

In summer and fall, when jellyfish often abound in temperate estuaries (e.g. Purcell et al. 2001), these systems are usually characterized by stratified or relatively nutrient-poor conditions in the upper water mass leading to a dominance of small phytoflagellates (Cushing 1989, Fisher et al. 1999). In the southern Baltic Sea, phosphorus (P) availability typically limits plankton growth in late summer (Grönlund et al. 1996, Nausch et al. 2004, Moisander et al. 2007), which was consistent with the high $\mathrm{N}: \mathrm{P}$ ratios throughout the experiment ( $\mathrm{P}$ was never detectable). We speculate that $\mathrm{P}$ limitation constrained cascading effects caused by Mnemiopsis leidyi grazing on mesozooplankton; only slightly elevated levels of chl $a$ in the treatment with $M$. leidyi were observed. Probably, the increased biomass of dinoflagellates upon relief from mesozooplankton grazing was facilitated by their mixotrophic lifestyle. The idea of nutrient availability constraining cascading effects of jellyfish is consistent with results from a mesocosm experiment in a coastal lagoon (Pitt et al. 2007).

Grazing-related processes and jellyfish tissue release ammonia and DOC (Nemazie et al. 1993, Hansson \& Norrman 1995, Nagata 2000, Pitt et al. 2009, Condon et al. 2011). We therefore anticipated a strong bottom-up effect in the Mnemiopsis leidyi treatments. Surprisingly, DOC concentration was similar in all treatments, as were bacterial abundance, activity, and community composition. DOC released from $M$. leidyi has been shown to be metabolized quickly by bacterioplankton (Condon et al. 2011). However, based on published release rates from M. leidyi tissue (Condon et al. 2011), the DOC release from the $M$. leidyi in our experiment was trivial $\left(\sim 0.02 \mu \mathrm{mol} \mathrm{l}^{-1} \mathrm{~h}^{-1}\right.$; data not shown). Whereas bacterial production increased with the DOC level between $t_{24}$ and $t_{72}$, reflecting bacterial utilization and food web production of DOC, respectively, the similarity between treatments indicates that predatory processes in the controls generated DOC at a magnitude similar to that related to $M$. leidyi activity. This idea is also supported by the finding of no differences in ectoenzymatic activities between treatments.

The gradual accumulation of DOC during the experiment may partly reflect that bacterial DOC utilization was nutrient limited (Zweifel et al. 1993, 1995), which is consistent with the undetectable $P$ levels and the low bacterial biomass-specific growth rates of $\leq 0.07 \mathrm{~d}^{-1}$ (data not shown). Also, the decreasing bacterial abundance and production in conjunction with the increased flagellate abundance towards the end of the experiment correspond to a 'malfunctioning microbial loop' scenario where mineral nutrients in combination with food web mechanisms control bacterial carbon consumption (Thingstad et al. 1997). Under richer nutrient regimes, bacterioplankton composition may change in response to trophic cascades (Zöllner et al. 2003, 2009) and to DOC released from Mnemiopsis leidyi (Condon et al. 2011). However, compositional changes appear delayed relative to changes in bacterial activity and abundance (Zöllner et al. 2003). Thus, in our experiment, the slow bacterial growth likely explains the minor temporal compositional shift and the lack of differences in bacterial community composition between treatments.

Our study demonstrates that a Mnemiopsis leidyi biomass comparable to that of the southern Baltic Sea ( 38 $\mathrm{g} \mathrm{WW} \mathrm{m}^{-3}$; Kube et al. 2007), but much lower than M. leidyi biomasses in the south-western Baltic Sea (up to $\sim 600 \mathrm{~g} \mathrm{WW} \mathrm{m}^{-3}$; Javidpour et al. 2009) or 
in US estuaries ( 150 to $188 \mathrm{~g} \mathrm{WW} \mathrm{m}^{-3}$; Kremer \& Nixon 1976, Condon \& Steinberg 2008), affects the higher trophic level of the food web. While M. leidyi almost depleted mesozooplankton populations, the low $\mathrm{P}$ conditions prevailing in the southern Baltic Sea in late summer limited trophic cascades beyond the phytoplankton level, as well as bottom-up responses, at least in a short-time perspective. Hence, the magnitude and characteristics of food web consequences driven by the presence and activity of $M$. leidyi appear tightly linked to the prevailing nutrient regime.

Acknowledgements. This work was supported by the BONUS+ project BAZOOCA (Baltic Zooplankton Cascades) through the Swedish Research Council for Environment, Agricultural Sciences and Spatial Planning; FORMAS; 20081893; 2008-1882) and through the FORMAS strategic research program Ecochange to Linnaeus University and a grant from the Research Council of Norway (190304/S40) to A.H. We appreciate the constructive suggestions from the reviewers, which improved the manuscript.

\section{LITERATURE CITED}

Acuña JL, Lopez-Urrutia A, Colin S (2011) Faking giants: the evolution of high prey clearance rates in jellyfishes. Science 333:1627-1629

Berggreen U, Hansen B, Kiørboe T (1988) Food size spectra, ingestion and growth of the copepod Acartia tonsa during development-implications for determination of copepod production. Mar Biol 99:341-352

Bleiwas AH, Stokes PM (1985) Collection of large and small food particles by Bosmina. Limnol Oceanogr 30: 1090-1092

> Boström KH, Simu K, Hagström Å, Riemann L (2004) Optimization of DNA extraction for quantitative marine bacterioplankton community analysis. Limnol Oceanogr Methods 2:365-373

Burns CW (1968) Relationship between body size of filterfeeding Cladocera and maximum size of particle ingested. Limnol Oceanogr 13:675-678

Colin SP, Costello JH, Hansson LJ, Titelman J, Dabiri JO (2010) Stealth predation and the predatory success of the invasive ctenophore Mnemiopsis leidyi. Proc Natl Acad Sci USA 107:17223-17227

Condon RH, Steinberg DK (2008) Development, biological regulation, and fate of ctenophore blooms in the York River estuary, Chesapeake Bay. Mar Ecol Prog Ser 369: 153-168

> Condon RH, Steinberg DK, del Giorgio PA, Bouvier TC, Bronk DA, Graham WM, Ducklow HW (2011) Jellyfish blooms result in a major microbial respiratory sink of carbon in marine systems. Proc Natl Acad Sci USA 108: 10225-10230

> Costello JH, Sullivan BK, Gifford DJ, Van Keuren D, Sullivan LJ (2006) Seasonal refugia, shoreward thermal amplification, and metapopulation dynamics of the ctenophore Mnemiopsis leidyi in Narragansett Bay, Rhode Island. Limnol Oceanogr 51:1819-1831
Cowan JH Jr, Houde ED (1993) Relative predation potentials of scyphomedusae, ctenophores and planktivorous fish on ichthyoplankton in Chesapeake Bay. Mar Ecol Prog Ser 95:55-65

> Cushing DH (1989) A difference in structure between ecosystems in strongly stratified waters and in those that are only weakly stratified. J Plankton Res 11:1-13

Edler L (1979) Recommendations for marine biological studies in the Baltic Sea. Phytoplankton and chlorophyll. Balt Mar Biol Pub 5:1-38

Finenko GA, Kideys AE, Anninsky BE, Shiganova TA and others (2006) Invasive ctenophore Mnemiopsis leidyi in the Caspian Sea: feeding, respiration, reproduction and predatory impact on the zooplankton community. Mar Ecol Prog Ser 314:171-185

Fisher TR, Gustafson AB, Sellner K, Lacouture R and others (1999) Spatial and temporal variation of resource limitation in Chesapeake Bay. Mar Biol 133:763-778

Fuhrman JA, Azam F (1982) Thymidine incorporation as a measure of heterotrophic bacterioplankton production in marine surface waters: evaluation and field results. Mar Biol 66:109-120

> Gasol JM, del Giorgio PA (2000) Using flow cytometry for counting natural planktonic bacteria and understanding the structure of planktonic bacterial communities. Sci Mar 64:197-224

Govoni JJ, Olney JE (1991) Potential predation on fish eggs by the lobate ctenophore Mnemiopsis leidyi within and outside the Chesapeake Bay Plume. Fish Bull 89:181-186

> Granéli E, Turner JT (2002) Top-down regulation in ctenophore-copepod-ciliate-diatom-phytoflagellate communities in coastal waters: a mesocosm study. Mar Ecol Prog Ser 239:57-68

Grasshoff K, Ehrhardt M, Kremling K (1983) Methods of seawater analysis. Verlag Chemie, Weinheim

Grönlund L, Kononen K, Lahdes E, Mäkelä K (1996) Community development and modes of phosphorus utilization in a late summer ecosystem in the central Gulf of Finland, the Baltic Sea. Hydrobiologia 331:97-108

> Hansson LJ, Norrman B (1995) Release of dissolved organic carbon (DOC) by the scyphozoan jellyfish Aurelia aurita and its potential influence on the production of planktic bacteria. Mar Biol 121:527-532

Hay SJ, Kiørboe T, Matthews A (1991) Zooplankton biomass and production in the North Sea during the Autumn Circulation experiment, October 1987-March 1988. Cont Shelf Res 11:1453-1476

Hernroth L, Ackefors H (1979) The zooplankton of the Baltic proper. A long term investigation of the fauna, its biology and ecology. Rep Fish Bd Sweden, Inst Mar Res $2: 1-60$

Hurlbert SH (1984) Pseudoreplication and the design of ecological field experiments. Ecol Monogr 54:187-211

Janas U, Zgrundo A (2007) First record of Mnemiopsis leidyi A. Agassiz, 1865 in the Gulf of Gdansk (southern Baltic Sea). Aquat Invasions 2:450-454

Jaspers C, Titelman J, Hansson LJ, Haraldsson M, Ditlefsen CR (2011) The invasive ctenophore Mnemiopsis leidyi poses no direct threat to Baltic cod eggs and larvae. Limnol Oceanogr 56:431-439

> Javidpour J, Molinero JC, Peschutter J, Sommer U (2009) Seasonal changes and population dynamics of the ctenophore Mnemiopsis leidyi after its first year of invasion in the Kiel Fjord, Western Baltic Sea. Biol Invasions 11:873-882 
Jespersen AM, Christoffersen K (1987) Measurements of chlorophyll a from phytoplankton using ethanol as extraction solvent. Arch Hydrobiol 109:445-454

Kankaala P, Johansson S (1986) The influence of individual variation on length biomass regressions in three crustacean zooplankton species. J Plankton Res 8:1027-1038

Kragh T, Søndergaard M (2004) Production and bioavailability of autochthonous dissolved organic carbon: effects of mesozooplankton. Aquat Microb Ecol 36:61-72

Kremer P (1979) Predation by the ctenophore Mnemiopsis leidyi in Narragansett Bay, Rhode Island. Estuaries 2: 97-105

Kremer P (1994) Patterns of abundance for Mnemiopsis in US coastal waters - a comparative overview. ICES J Mar Sci 51:347-354

Kremer P, Nixon S (1976) Distribution and abundance of the ctenophore, Mnemiopsis leidyi in Narragansett Bay. Estuar Coast Mar Sci 4:627-639

Kube S, Postel L, Honnef C, Augustin CB (2007) Mnemiopsis leidyi in the Baltic Sea-distribution and overwintering between autumn 2006 and spring 2007. Aquat Invasions 2:137-145

Kuuppo-Leinikki P, Kuosa H (1989) Preservation of picoplanktonic cyanobacteria and heterotrophic nanoflagellates for epifluorescence microscopy. Arch Hydrobiol 114:631-636

Menden-Deuer S, Lessard EJ (2000) Carbon to volume relationships for dinoflagellates, diatoms, and other protist plankton. Limnol Oceanogr 45:569-579

Mills CE (2001) Jellyfish blooms: Are populations increasing globally in response to changing ocean conditions? Hydrobiologia 451:55-68

> Moisander PH, Paerl HW, Dyble J, Sivonen K (2007) Phosphorus limitation and diel control of nitrogen-fixing cyanobacteria in the Baltic Sea. Mar Ecol Prog Ser 345: 41-50

Muyzer G, Smalla K (1998) Application of denaturing gradient gel electrophoresis (DGGE) and temperature gradient gel electrophoresis (TGGE) in microbial ecology. Antonie Leeuwenhoek 73:127-141

> Muyzer G, De Waal EC, Uitterlinden AG (1993) Profiling of complex microbial populations by denaturing gradient gel electrophoresis analysis of polymerase chain reaction-amplified genes coding for 16S rRNA. Appl Environ Microbiol 59:695-700

Nagata T (2000) Production mechanisms of dissolved organic matter. In: Kirchman D (ed) Microbial ecology of the ocean, 1st edn. Wiley-Liss, New York, NY, p 121-152

Nausch M, Nausch G, Wasmund N (2004) Phosphorus dynamics during the transition from nitrogen to phosphate limitation in the central Baltic Sea. Mar Ecol Prog Ser 266:15-25

> Nemazie DA, Purcell JE, Glibert PM (1993) Ammonium excretion by gelatinous zooplankton and their contribution to the ammonium requirements of microplankton in Chesapeake Bay. Mar Biol 116:451-458

Oguz T, Fach B, Salihoglu B (2008) Invasion dynamics of the alien ctenophore Mnemiopsis leidyi and its impact on anchovy collapse in the Black Sea. J Plankton Res 30: 1385-1397

> Pitt KA, Kingsford MJ, Rissik D, Koop K (2007) Jellyfish modify the response of planktonic assemblages to nutrient pulses. Mar Ecol Prog Ser 351:1-13

Pitt KA, Welsh DT, Condon RH (2009) Influence of jellyfish blooms on carbon, nitrogen and phosphorus cycling and plankton production. Hydrobiologia 616:133-149

Purcell JE, Decker MB (2005) Effects of climate on relative predation by scyphomedusae and ctenophores on copepods in Chesapeake Bay during 1987-2000. Limnol Oceanogr 50:376-387

Purcell JE, Shiganova TA, Decker MB, Houde ED (2001) The ctenophore Mnemiopsis in native and exotic habitats: US estuaries versus the Black Sea basin. Hydrobiologia 451:145-176

Putt M, Stoecker DK (1989) An experimentally determined carbon-volume ratio for marine oligotrichous ciliates from estuarine and coastal waters. Limnol Oceanogr 34: 1097-1103

Rapoza R, Novak D, Costello JH (2005) Life-stage dependent, in situ dietary patterns of the lobate ctenophore Mnemiopsis leidyi Agassiz 1865. J Plankton Res 27: 951-956

- Richardson AJ, Bakun A, Hays GC, Gibbons MJ (2009) The jellyfish joyride: causes, consequences and management responses to a more gelatinous future. Trends Ecol Evol 24:312-322

> Riemann L, Titelman J, Båmstedt U (2006) Links between jellyfish and microbes in a jellyfish dominated fjord. Mar Ecol Prog Ser 325:29-42

Riisgard HU, Bottiger L, Madsen CV, Purcell JE (2007) Invasive ctenophoe Mnemiopsis leidyi in Limfjorden (Denmark) in late summer 2007-assessment of abundance and predation effects. Aquat Invasions 2:395-401

> Roohi A, Kideys AE, Sajjadi A, Hashemian A and others (2010) Changes in biodiversity of phytoplankton, zooplankton, fishes and macrobenthos in the Southern Caspian Sea after the invasion of the ctenophore Mnemiopsis leidyi. Biol Invasions 12:2343-2361

Ross PE, Munawar M (1981) Preference for nanoplankton size fractions in Lake Ontario zooplankton grazing. J Gt Lakes Res 7:65-67

Shiganova TA (1998) Invasion of the Black Sea by the ctenophore Mnemiopsis leidyi and recent changes in pelagic community structure. Freshw Biol 7:305-310

> Shiganova TA, Mirzoyan ZA, Studenikina EA, Volovik SP and others (2001) Population development of the invader ctenophore Mnemiopsis leidyi, in the Black Sea and in other seas of the Mediterranean basin. Mar Biol 139: 431-445

Smith DC, Azam F (1992) A simple, economical method for measuring bacterial protein synthesis rates in seawater using ${ }^{3} \mathrm{H}$-leucine. Mar Microb Food Webs 6:102-114

> Sommer U, Sommer F (2006) Cladocerans versus copepods: the cause of contrasting top-down controls on freshwater and marine phytoplankton. Oecologia 147:183-194

Sommer U, Stibor H (2002) Copepoda-Cladocera-Tunicata: the role of three major mesozooplankton groups in pelagic food webs. Ecol Res 17:161-174

Stanlaw KA, Reeve MR, Walter MA (1981) Growth, food, and vulnerability to damage of the ctenophore Mnemiopsis mccradyi in its early life-history stages. Limnol Oceanogr 26:224-234

Stibor H, Vadstein O, Diehl S, Gelzleichter A and others (2004) Copepods act as a switch between alternative trophic cascades in marine pelagic food webs. Ecol Lett $7: 321-328$

Stoecker DK, Verity PG, Michaels AE, Davis LH (1987) Feeding by larval and post-larval ctenophores on microzooplankton. J Plankton Res 9:667-683

Sullivan LJ, Gifford DJ (2004) Diet of the larval ctenophore 
Mnemiopsis leidyi A. Agassiz (Ctenophora, Lobata). J Plankton Res 26:417-431

Sullivan LJ, Gifford DJ (2007) Growth and feeding rates of the newly hatched larval ctenophore Mnemiopsis leidyi A. Agassiz (Ctenophora, Lobata). J Plankton Res 29: 949-965

Sullivan BK, Van Keuren D, Clancy M (2001) Timing and size of blooms of the ctenophore Mnemiopsis leidyi in relation to temperature in Narragansett Bay, RI. Hydrobiologia 451:113-120

Tendal OS, Jensen KR, Remington K (2007) Invasive ctenophore Mnemiopsis leidyi widely distributed in Danish waters. Aquat Invasions 2:455-460

Thingstad TF, Hagstrom A, Rassoulzadegan F (1997) Accumulation of degradable DOC in surface waters: Is it caused by a malfunctioning microbial loop? Limnol Oceanogr 42:398-404

Titelman J, Riemann L, Sörnes TA, Nilsen T, Griekspoor P, Båmstedt U (2006) Turnover of dead jellyfish: stimulation and retardation of microbial activity. Mar Ecol Prog Ser 325:43-58

Turk V, Lucic D, Flander-Putrle V, Malej A (2008) Feeding of Aurelia sp. (Scyphozoa) and links to the microbial food

Editorial responsibility: Antonio Bode, A Coruña, Spain web. PSZNI: Mar Ecol 29:495-505

Utermöhl H (1958) Zur Vervollkommnung der quantitativen Phytoplankton-Methodik. Mitt Int Ver Theor Angew Limnol 9:1-38

> Vuorinen I, Hänninen J, Viitasalo M, Helminen U, Kuosa H (1998) Proportion of copepod biomass declines with decreasing salinity in the Baltic Sea. ICES J Mar Sci 55: 767-774

Zöllner E, Santer B, Boersma M, Hoppe HG, Jurgens K (2003) Cascading predation effects of Daphnia and copepods on microbial food web components. Freshw Biol 48: 2174-2193

> Zöllner E, Hoppe HG, Sommer U, Jürgens K (2009) Effect of zooplankton-mediated trophic cascades on marine microbial food web components (bacteria, nanoflagellates, ciliates). Limnol Oceanogr 54:262-275

- Zweifel UL, Norrman B, Hagström A (1993) Consumption of dissolved organic carbon by marine bacteria and demand for inorganic nutrients. Mar Ecol Prog Ser 101: 23-32

Zweifel UL, Wikner J, Hagström A, Lundberg E, Norrman B (1995) Dynamics of dissolved organic carbon in a coastal ecosystem. Limnol Oceanogr 40:299-305

Submitted: January 6, 2012; Accepted: April 18, 2012

Proofs received from author(s): July 10, 2012 